Alexander II. の戴冠式の際には Berkut (イメワシ)を ()renburg から収 り等せて使用したと云ふ記事がある。

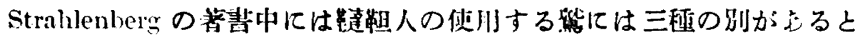

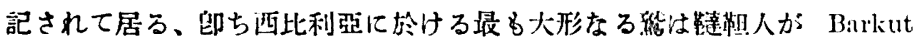

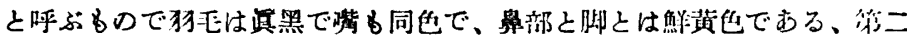
種は Kutschuran と呼ばれ、符三、即ち最小犁は Kara-kus! と呼ばれる。

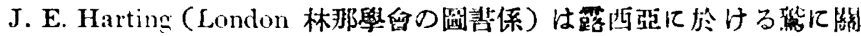
して西歷千八百九十非雜誌“"The Field”に次の論文を發裴し:。

"Trained Eagle."

"The Eagles used ly Russian Falconers."

"The Berkut of Turkestan."

\title{
十萬邪の燕莡救ふ 維納動物保護協會の活動
}

媵學博士时满之助

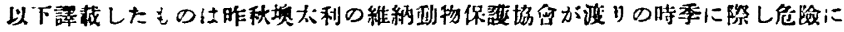

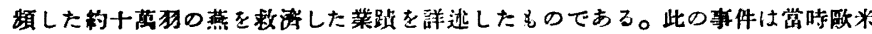
各國で多人のたンセーションを起し我が國でも二三の新聞、雜誌によつて簡單に 報道されたので御承知の方多いと思ふ。

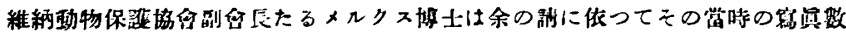

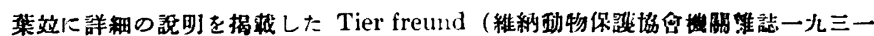

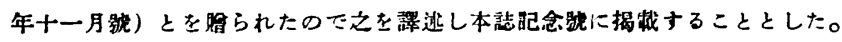

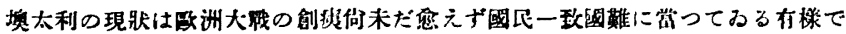

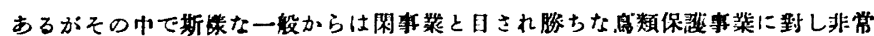

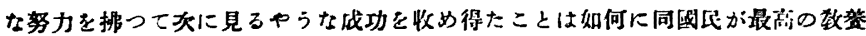

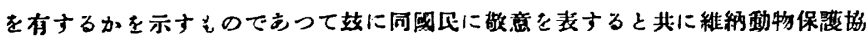

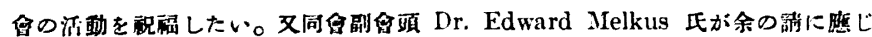

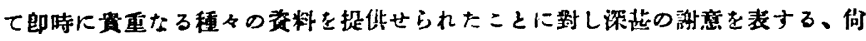

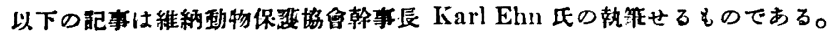




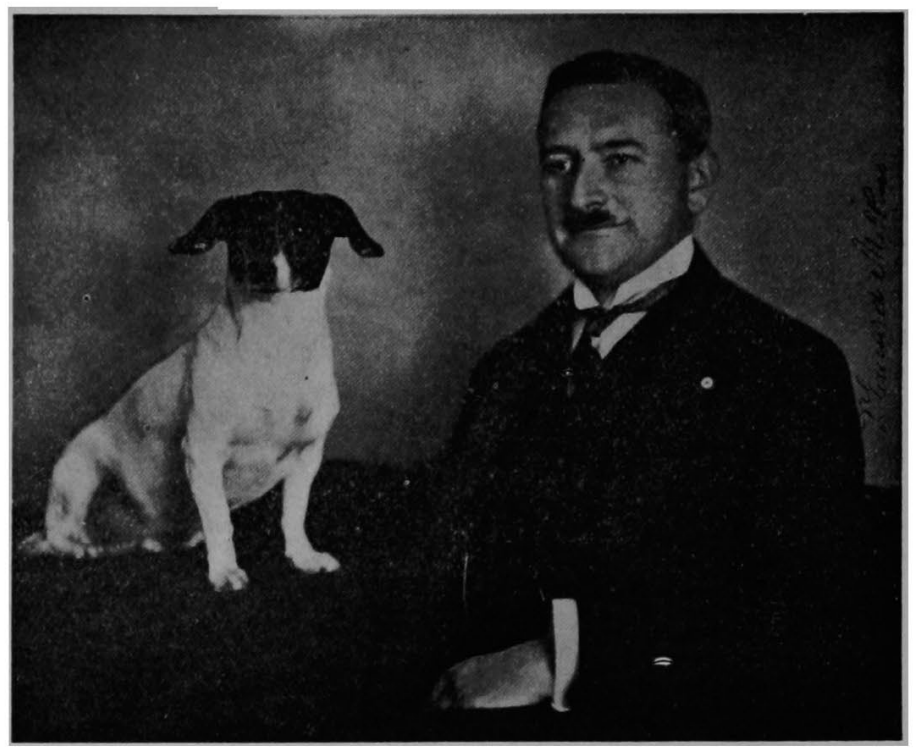

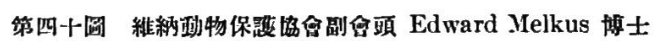

嗳かい低風が吹き初めて快い季節の到來を告げ、禹物を蘇生せしむる やうな日光が今迄怗死して居た自然を目醒まして新几芽生一る生派て入ら しめ、接骨标や荲が初めて花を付けるやうな時分になるといつもきまつて 我愛する良友、燕が再びやつて來る。去つて行く時には目立ちもせす氣付 かれもしないが、再で跕つて来ると今度は人間は大騒ざしてから敬迎す

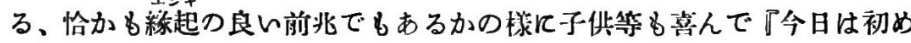
て燕を見たよ』と話し合ふ。

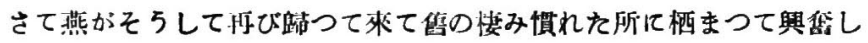
てチューチュー崹いて居る柡は恰も彼等が冬の間滞在して居た䒪れ果てた

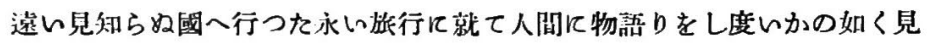
える。人间は彼等が遠虑なくいま再び秋几見捨てい行つた古巢へ行くこと

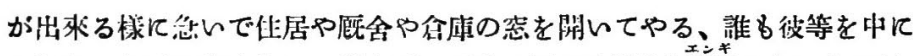
入れないと言ふ者はない、卧を言へば此つ國では「燕は䋑起の良いものだ」 と言ふ信仰は大變なもので、若し夏の間漞しくその生活狀熊を見てわた一 


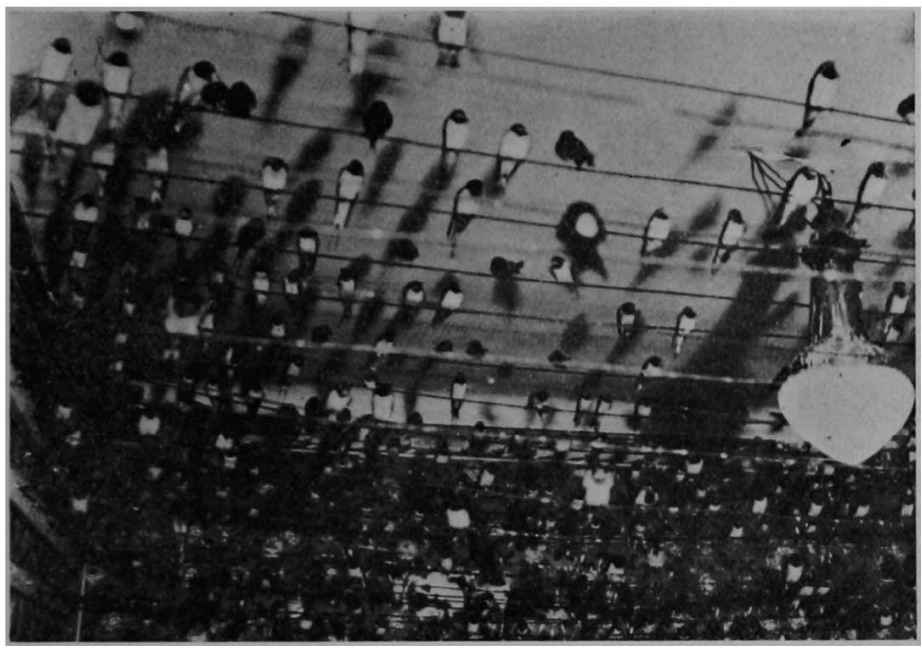

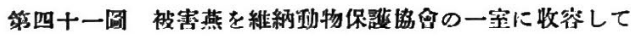

休蓉せしめつ〉ある所

番つ燕が恐らく長い道中で不幸てでもかかつて來ないやらなととですすら うものなら些が殘念に思ふ栐な状態である。

さて㘕つて柬れば役等は再び元氣な忙しい活䡃を初める、殘してあつ

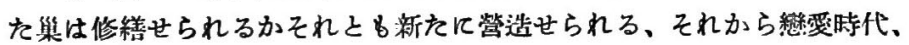

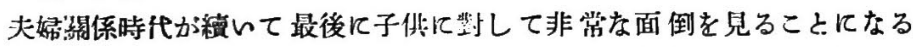
が、その子供のためには燕の父と丹とは夏中大變な苦管をする、そして此 の小さな燕つ仔が充分力付いて美しい晚夏に嗳かい息氟を出す栐になれば 早やモウ彼等江第二の故能一之飛び去つて行く淮借て取脚かる、之は研究 しても果てしの焎い自然の原则て從つて彼等が㫮からやり来つた柏慣で刑

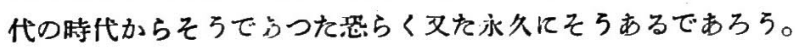

處がだ、今年初めてその燕の飛行の禁史几變つた事が起らねばなら

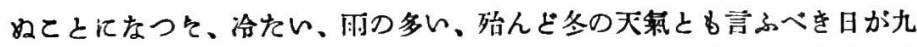
月の月になつてから續いてその第めに彼等の多くは此の波去期に自分の力 で飛び卡つて行くことが出來なくなつた、此の事蝠は燕て取つては只簡單 几九月に突然十二月が來たものだとは考へられない、從つて彼等には一大 


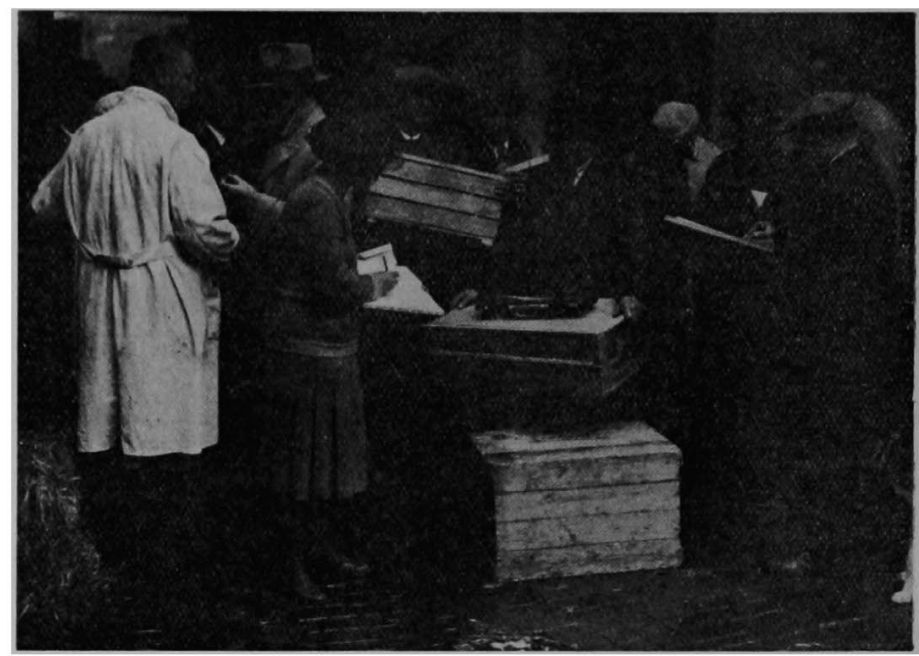

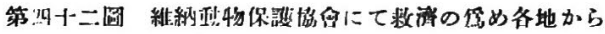
被宫燕を果めつょある所

桨難となつてふり棑つて來た、と言ふのは佖等が南方への飛行中に疲勞し 切つてその上ヅブ㽭れになつて「ウイーン..とその郊外の上空で群をなし て落下せねばならね破目になり止むを得す人阔の救助を姴する事となつた が、その救牥は結局非常な成功をかち得たのであつた。

さて斯栐な事翛で燕の救功が始まり內外國全般反亘つて非常な七ンセ ーションを懙起し最もその時正を得たる有刣な仕事として唯された事であ るが之汢永久に『ウイーン動物保護協會』の歴史に最も美しき名譽ある一 页を飾るであろ5、此の燕つ救助を具先に組䄉立てて飛行機や汽車を用みて 南万へ輸运する事の面倒を允たものは我協曾であつた事を朋示する篇めに 次に詳細に之を記して見やうと思ふ。

『ウイーン』の近くの『ランネルスドルフ.タから初めて電話で知らせ て來た時に否ミは遖ぐ新閆で吾々は点んで此の落下した燕の世話をすると 言ふ事を廣告させた、此つ㠿知が豫想外の成果を舉げ老いたるも若をも貧 者も富者も、一言にして言へば我全或民が燕の菂集に寗㞦して吳れた、地

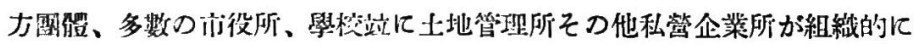




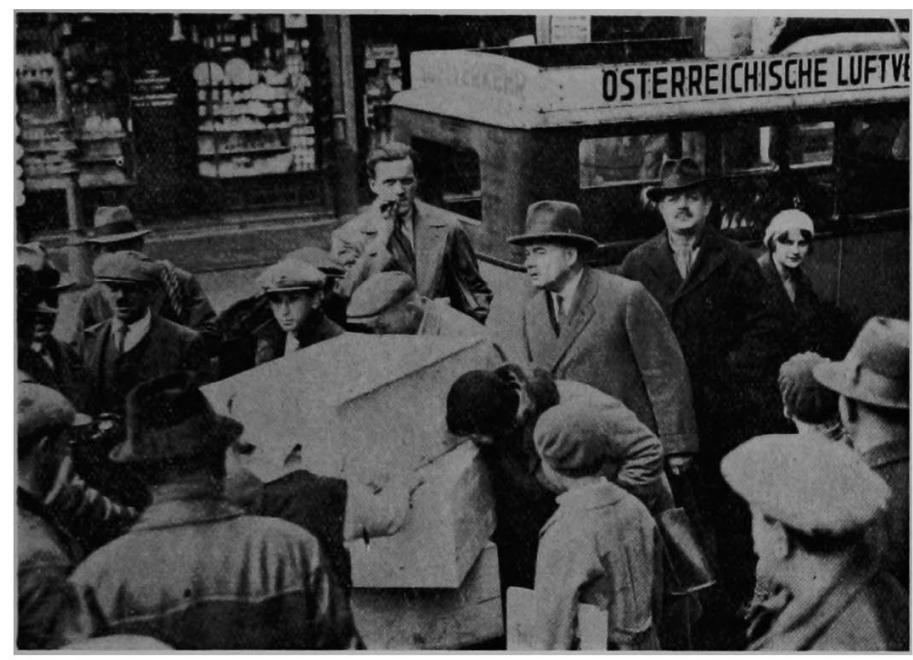

第四十三图 休善を與へたる多數の燕を箱諳として自動車にて

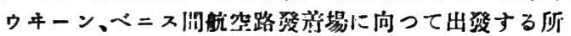

救助作菜をなし㫷も夜も問斷なく電話がかかつて運んで來べを燕を集めて わる場所を和らせて柬たので二人つ係囬が交代で此の報告を取次ぎ吾々は 此の超人間的要求几應するためには坖能力を發战せねばならなかつた、着 手して間もなく自分共の二輛の救助車の外飞佾ほ二臺わさから自動車を偕

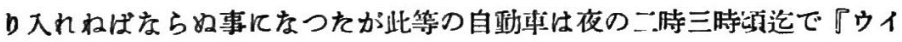
ーン』やその近郊から集めを燕を運んで來た、夜分休荟時閌の多くは傤牲

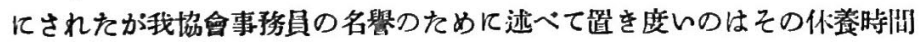
を喜んで鈛牲にした事である、皆つ者が言はよ゙保棭舍の中に容れてある新 しい珍客の面倒を見る事て於て競凫をしたつであつた。

最初『ウイーン』の東方のある地方から救助を言ふて來た時て吾くは 遖ぐ、之は北方から來た大群の燕であつて此所で疲營し切って落下したも のに相違ないと推定したが此の推定は後日『シニウェッカート』の我地方 團輹刀所へ一旸の足輪を筷めた燕が持つて來られてそれが 129.538 Rossit-

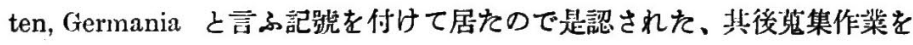
續けて居る中に肋に二度目の睬化で生れて天桨の來ない前に南方へ飛び 


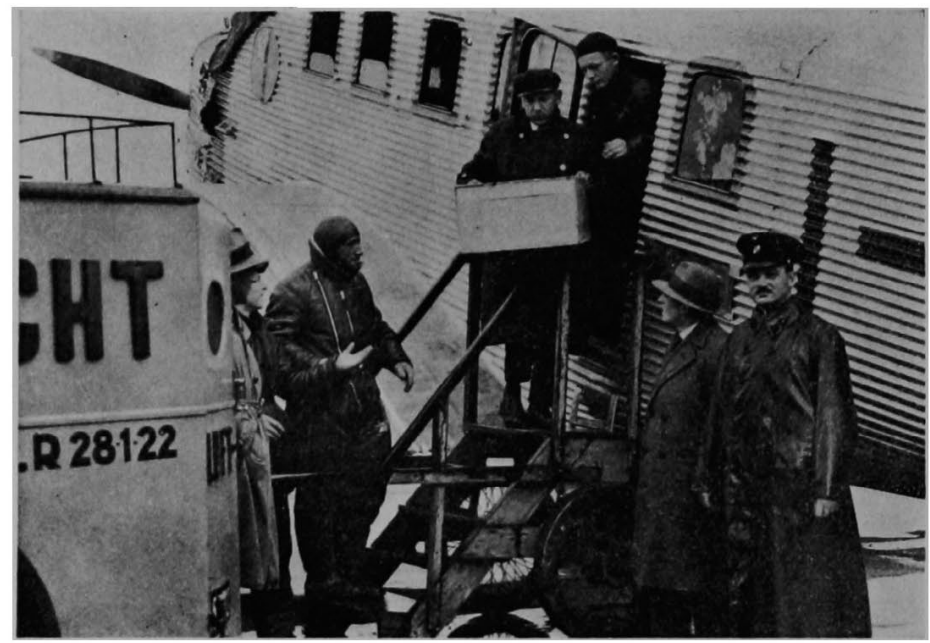

第四十四圆 箱詰めにした燕を飛行機に拒して伊太利に 輸䢒せんとする所

去つて行くにはまだ充分力も付いて居らす且つ經驗もなかつた燕も運んで 來られたが之は鬼に触まだ吾々の所に残してある。

佩然にも吾及は『フリードリッヒ、カイゼル、ガッ七』七十番地所在の 我動物保護食に空いた住宅を一杆持つて居たので之を大急ぎで此等珍客の 收容のために仕立て上げた、部屋を急いで暖めて澤山の針金を引張りその 上に彼等を㙨千となく栖まらせた、燕は人間に對して更て恐怖心は持たす 誰でも景入つて來る人があると直ぐに手や肩や頭の上に止まるのを見ると

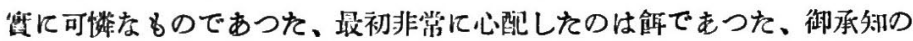
通り燕は飛んで居る中に飭を搜すものであるが涬山の飢えた䯣は小さいが

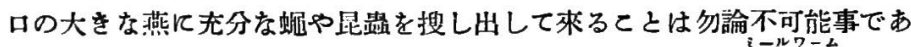

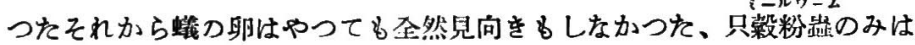
嘴の前へ差し出すと食り喰つたので之で忍も售望みの曙光を認めた、何し ろ澤山の燕に對して一ネ慨を與へることは不可能であつたから最初は生き

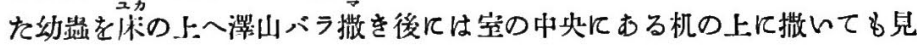
たが此の試みも短張り旨く行つた、此の可愛らしい小動物共が次ぎ次ぎ 


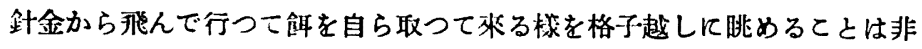

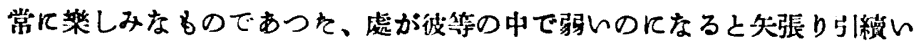

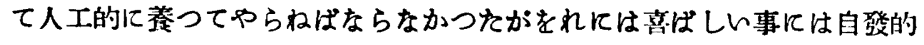
飞助手を申込んで吳れる人が澤山有つた。

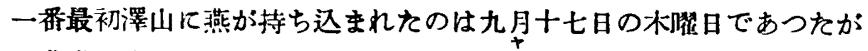
其日任非常に寒い虫の日で朝早くから晚まで止みなしに雨か降つて居た、 『ヒルシュステッテン』で其處の仕民達が集めた二千旸の燕を皘んだ貨物自 働東が來ると電話で知らせて來たのは婏の十時であつた、それから年牛に 叉一豪貨物自動車が『シウェツカート』から五千弱の燕を稍んで來た、此

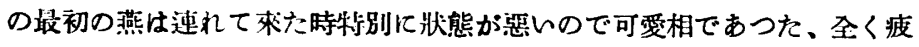

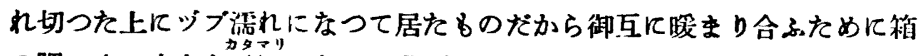
の隅の方に大をな塊になつてらづくまつて居た、大急ぎで箱を喛めた部 屋の中へ運んでーつ一つ取り出した、それから後に運んで來た燕は最初に 來えものよりは遥かに生氣があり元氣であつた。

燕を保護舍の中に永く止めて置くと云ふ事は色々の理由で出來ないて とであつたから吾々は何等かの方法で之を南方へ鐱邆する淮跲をせねばな らなかつた。

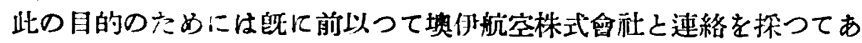

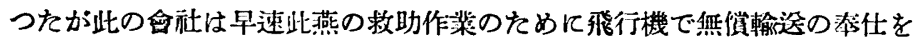
ナる旨を舟し出て哭れた。

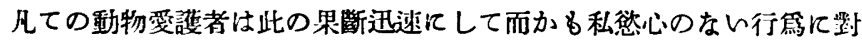
して兩會社几特別の謝意を表する義務がある何となれば若し兩社の㥪牲的 の車出がなかつたならば此の愛すべ有用な小動物の幾千が全诚すること は绝れなかつたであらら。

さて斯くの如くにして㱠んど每日燕を稍んた飛行機が『ヴェニス』に 向つて飛び其處で「リドー』と着陸すると直ちに此の動物は墺國领事馆つ 代表者と『ヴェニス』動物保護協會の代表者之の立合の下飞操縱者几依つ て自的に放えれた、吾々の請て传らて『ヴェニス』市長も時折燕の到着す る時几役人を寄越して哭れた、九月十九日の土眼日几我健氣なる支配人が 保護舍の室は燕で皆滿員になつたと電話で言つて來た時だけは後から來る 燕に對して席を設けるために晚に發車する『ヴェニス』行 D 列車几暖め た偊車を連絬する決心をせねばならなかつた殊てその翌日の日曜日には飛

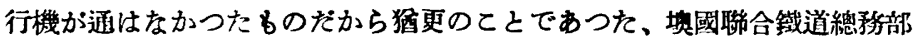


の商事部長ドクトル、ラウシェル氏は以 前商工省に居た時 分一大の動物愛蓝 者として活動したてとは吾人が疾くに翢いて居ることであるが同氏が特别 の厚意を寄せられたのと伊太利公使 Giacinte Auriti 氏からも非常な嗳助 を受けた御䔖で列車の發車までに僅かしかない時間の中に萬事が滞りなく 片付けられた、此の汽車輸揆で揆つたものの中には各所から來た燕の中で 以前人間の手で運んで來た燕の恐らく大部分があつた、澤山の包裝物が货 物車で停車場へ運搬されそこで文注意して蕉借された列車の中へ稍み替 へられた、此の輸远に附き添つて行つたハラント秘珰は發車後直ぐに漯山 の容器を阙くことが出來たので餂数の燕は暖められた車の中に陣取つた、 佲太利公使から鿓つた推蔍状の御险で列車は國境で何等四角張つた形式 も要らないで樂々と通過が出來た、翌朝列本が雪に敗はれたアルペンの山 を超えた時喛かい南方の氣候の中で昆蟲や蝶蛾の澤山居る前で直ぐ此の 燕を次ぎ次をと放し初めたので『ヴェニス』に到着した時にはその殘りが 僅か許り居つたに過ぎかつた。

總體で吾々が輸送を筧施したものは次の通りである。

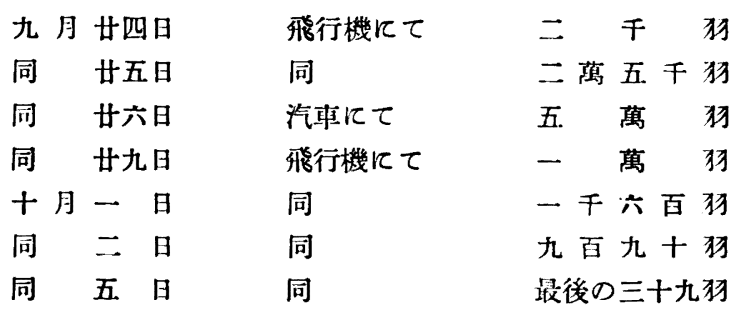

之で見ると『ウイーン』動物保亚協會に佉つて以上の樣な方法で南方 一揆られた燕の總数は約八英九千旸であつた。

一禹四千六百七十八狗までは精密化数へる事が出來たがそれから後は 最早简單に數へることは山來ないので先づ正碓と考へられる見皘り數で㴖 足せねばならなかつた、此の數字に墺國動物保護協會と『゙ルガレッテン、 ギュルテル』附近の墺國一般動物保護聯盟が引受けて輸送した燕を加へる なら猫以上の夥しい数字に上るのであるが、此等の凡ての燕に吾々は 救助を興へたのであつた。

燕は特别て抪へた箱 $(100 \mathrm{~cm} . \times 50 \mathrm{~cm} . \times 30 \mathrm{~cm}$. $)$ 几入れて鐱送したが 此の箱には勿論充分な空氣穴を設け向ほ內部に止まり水も取付けを、それ から出來得る限り輸运前に慨を與へて然る後『アスペルン』の方へ飛行場へ 
と運んで行つた、吾々は燕を箱詰めにして圆くことを出來る才け短かくし て遠い輸送の苦痛をかけない椂にしてやりたかつたものだから月的地とし て『ヴェニス』を撰んだのである、『ヴェニス』への瓜行は二時閌牛乃系 三時間什しかかからなかつたが此の短かん飛行でも份汪且つ少数率の燕 (約五\%)が苦痛のために死することを免れなかつれのは殘念である、然か し兔觕彼等の大部分は救助することが出來た譯だ。

以上に依つて動物保護の一事莱が完成されたのであるが本事桨は第一 凡其の性質上單に䘫家の立場から言つて非常に有益であつたのみならす 我國民の道德上站几精利文化の上から見ても非常几貢蹊せられたことと考 へられる。『ウイーン』動物保護協會の此の燕に對する計剩は全世界の注 目を喚起したものも當然のことで、これで以つて善良なる墺國人の心底に 埧太利人は現今自分自身に非常行苦しめられて居る大心配があるにも拘ら 才倘经つ惱める動物に對して斯くも多大の同情を寄せることが出來た事 に就て最る良い立證をした譯である。墺㽣と言ふ名前は其の㗬時再び第一

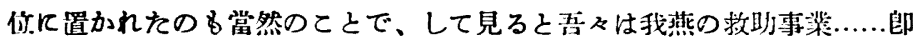
ち文化行䴇の尖端に在るもの......亿依つて我が小さき本國の名聲に赻なか らす貢㓺した事を磼く信して居る。

さて今や燕の救助作業も終りを告げたが故に望ネは之に就て特に望人 を嗳助して曲れた總ての人々に對し心からの感謝を述ふるために此の機會 を逸し度くないと思ふ、それは就中保護舍の中で疫れ切つた燕に慨を與へ る骨の折れる仕事をやつて呂れた多敖の自發的授助者、燕の持ち速ひれ自 己の自動車を全く私㥕を離れて使用させて吳れた自動車の持主、市役所、 土地管理所及び學校、涉ひに田舍で燕の蒐集を組䄉的にやつて下すつた我

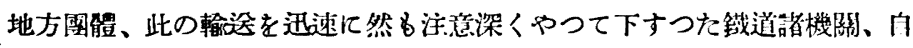

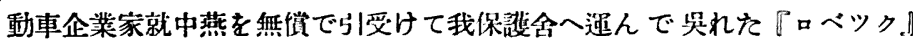

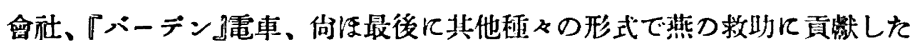
凡ゆる沫知の人々等て對し深甚の謝意を表する次第である。

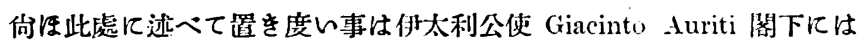
『ウイーン動物保護協會の金製名舉章を、墺國航空株式會社社長 Hafrat Deutelmoser 氏、貨物紹介者 Lerch 氏、少住 Walter ron Lux 氏、仍太 利航空會社の支配人 Cazitano Antonio Venturini 氏、伊太利飛行家 Umberto Bianchini 氏、及び『ヴェニス』動物保護協會 々長 Dr. G. Zironda 氏には各々銀製名譽章を贈呈したてとに對し吾人は非常に㴖足に思つて居 


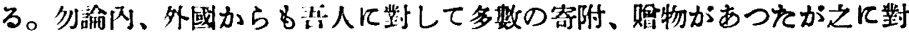

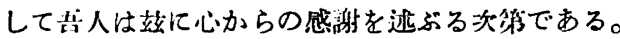

望人の報告は碓かに詯者の興味を喚起することであらうが此の報告を

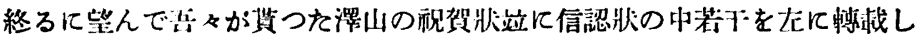
て見たいと思ふ。

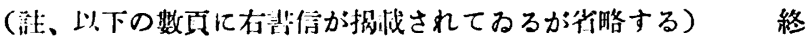

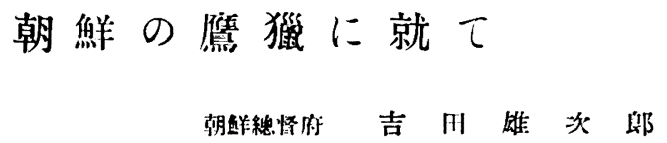

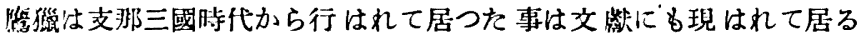
が、留際支那では隨分古くから各方面几然を使用したるので、軍用として

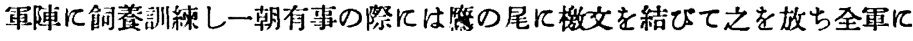

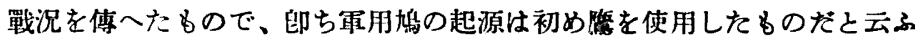

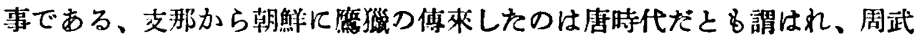

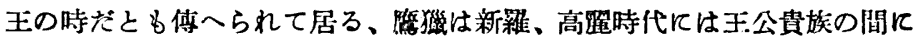

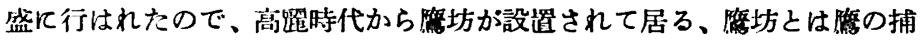

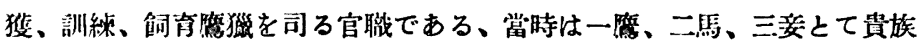

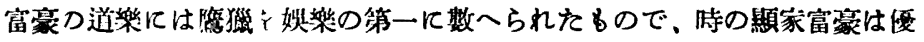
秀なる䉥と熙を持つ事を最も誇りとしたものであつた。

咸鏡道では今から五百四十年前李朝の開租李成柱が咸與、元山地方で

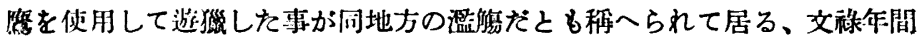

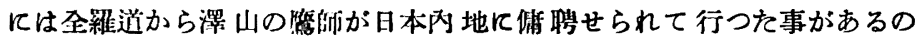
で、內地でも德川時代には盛に行はれたものであるが、維新後は文化の發 達に俳ひ自然に廢れ現在は殆ど見る事が出來ない核になつた様である。

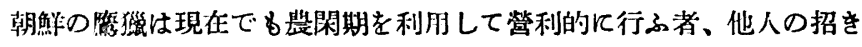

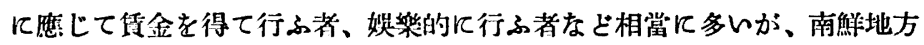
は近年著しく衰退して闹美旸数も少くなつたりれど、北鮮西鮮地方では今

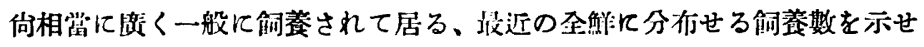
は下の如し。 